\title{
Distribution and isotopic composition of lead in bottom sediments from the hydrographic system of Belém, Pará (western margin of Guajará Bay and Carnapijó River) \\ Distribuição e composição isotópica do chumbo em sedimentos de fundo do sistema hidrográfico de Belém, Pará (margem oeste da Baía do Guajará e Rio Carnapijó) \\ Elma Costa Oliveira ${ }^{1 *}$, Jean Michel Lafon ${ }^{1}$, José Augusto Martins Corrêa ${ }^{1}$, Jully Hellen dos Santos Carvalho ${ }^{1,2}$
}

\begin{abstract}
This study first aimed to evaluate the effect of human activities on the distribution of lead within the estuarine system of Belém, Pará. This was achieved by studying the concentration and isotopic signature of $\mathrm{Pb}$ in bottom sediments from the western margin of Guajará Bay and from Carnapijó River, an area removed from the influence of the city of Belém. Secondly, the contribution of suspended matter in the transportation of anthropogenic $\mathrm{Pb}$ in Guajará Bay was evaluated. Third, the content and background isotopic signature of $\mathrm{Pb}$ in the hydrographic system of Belém was determined. Isotopic signatures of sediments from the western margin of Guajará Bay confirm an anthropogenic contribution of $\mathrm{Pb}$ throughout the entire bay. The $\mathrm{Pb}$ accumulation process has become more efficient over the last 10 years, and this can be attributed to the rapid population growth of Belém city. Sediments in Carnapijó River are not affected by human activities, and the average concentration values $\left(\mathrm{Pb}=19.6 \pm 3.7 \mathrm{mg} \mathrm{kg}^{-1}\right)$ and isotopic signatures $\left({ }^{206} \mathrm{~Pb} /{ }^{207} \mathrm{~Pb}=1.196 \pm 0.004\right)$ confirm the background $\mathrm{Pb}$ values previously proposed for the river system in the Belém region. The isotopic signatures of suspended matter on the eastern $\left({ }^{206} \mathrm{~Pb} /{ }^{207} \mathrm{~Pb}=1.188\right)$ and western $\left({ }^{206} \mathrm{~Pb} /{ }^{207} \mathrm{~Pb}=1.174\right)$ margins of Guajará Bay show that suspended matter is an efficient $\mathrm{Pb}$ transportation mechanism of domestic and industrial wastewater from Belém to the western margin of the Bay due to tidal effects at the confluence with Guamá River.
\end{abstract}

KEYWORDS: Lead isotopes; Bottom sediments; Belém estuarine system.

\begin{abstract}
RESUMO: Este trabalho teve como objetivos: (1) avaliar a extensão da ação antrópica sobre a distribuição do chumbo no sistema estuarino da regiáo de Belém, Pará, por meio do estudo da concentraçáo e assinatura isotópica de $\mathrm{Pb}$ em sedimentos de fundo da margem oeste da baía do Guajará e do rio Carnapijó, localizado em uma área mais afastada da influência da cidade de Belém; (2) avaliar a contribuição do material em suspensão como meio de transporte de Pb antropogênico na baía do Guajará; e (3) conferir os teores e assinatura isotópica de background de Pb no sistema hidrográfico de Belém. As assinaturas isotópicas dos sedimentos da margem oeste da baía do Guajará confirmam uma contribuição antropogênica para o Pb na escala de toda a baía. O processo de acumulação de Pb se tornou mais eficiente nos últimos 10 anos e deve estar ligado ao crescimento populacional acelerado da cidade de Belém. Os sedimentos do rio Carnapijó ainda não foram afetados pela ação antrópica e os valores médios de concentração $\left(\mathrm{Pb}=19,6 \pm 3,7 \mathrm{mg} \mathrm{kg}^{-1}\right)$ e assinatura isotópica $\left({ }^{206} \mathrm{~Pb}{ }^{207} \mathrm{~Pb}=1,196\right.$ $\pm 0,004)$ confirmam os valores de background de $\mathrm{Pb}$ anteriormente propostos para o sistema hidrográfico da região de Belém. As assinaturas isotópicas do material em suspensão nas margens oriental ${ }^{206} \mathrm{~Pb} P{ }^{20} \mathrm{~Pb}=$ 1,188) e ocidental $\left.{ }^{206} \mathrm{~Pb} P^{207} \mathrm{~Pb}=1,174\right)$ da baía do Guajará mostram que o material em suspensäo é um mecanismo eficiente de transporte do chumbo proveniente dos efluentes domésticos e industriais da cidade de Belém para a margem oeste da baía; em razão dos efeitos de maré na confluência com o rio Guamá.
\end{abstract}

PALAVRAS-CHAVE: Isótopos de Pb, Sedimentos de fundo, Sistema estuarino de Belém.

1'Institute of Geosciences, Universidade Federal do Pará, Belém (PA),Brazil.E-mails: ecoliveira2002@yahoo.com.br, lafonjm@ufpa.br, jamc@ufpa.br 2Federal Institute of Maranhão, Campus Pinheiro, Pinheiro (MA),Brazil. E-mail: jullyhellenc@yahoo.com.br 


\section{INTRODUCTION}

The geochemistry of sediments from rivers, estuaries, and coasts provides important information about sediment origin and environmental changes due to both natural and anthropogenic influences. Therefore, chemical composition of river sediments can generally depict a high degree of spatial variation in relation to provenance, river transport, and depositional environment (Roig et al. 2005). In addition to geochemical studies of trace elements, the application of radiogenic isotopes is widely employed in hydrological, geological and atmospheric studies, due to their capability to characterize natural and anthropogenic sources (Banner 2004). Lead, in particular, has acquired great importance in environmental studies as it has been demonstrated that, unlike other heavy metals, the isotopic signatures of $\mathrm{Pb}$ from anthropogenic and geogenic sources are distinct and can, therefore, be used as tracers of contamination sources for this element (Komarék et al. 2008, Kylander et al. 2010, Bird 2011).

In recent years, urban growth has occurred in a disorganized manner in the metropolitan area of Belém, and this is directly reflected in the quality of water and sediments in Guamá River and Guajará Bay, which constitute the main hydrological elements from the Belém's estuary system. Guajará Bay is suffering from environmental degradation, and this is gradually increasing due to the accelerated population and industrial growth of the city of Belém, and the related dumping of domestic and industrial wastewater without prior treatment, that causes damage to organisms and sediments (IDESP 1990). In contrast, the Guajará estuary has intense hydrodynamics and therefore a large capacity for pollutant dilution.

Guajará Bay is formed at the confluence of Acará and Guamá Rivers, west of the city of Belém, and extends almost to the island of Mosqueiro. At this point it meets the Bay of Marajó, which with Pará River forms the southern-most estuary system at the mouth of Amazon River. Numerous channels and islands, the largest island of which is the Onças Island, make up the left margin of Guajará Bay and separate the bay from the Pará River. The interaction between the river currents, tides, and waves results in an environment with high-energy hydrodynamic conditions. In this respect, the water dynamics and extreme seasonal variations are important factors influencing the concentration of suspended matter and the complexity of the sedimentation processes (Gregório \& Mendes 2009).

The study area is located on the western margin of Guajará Bay between $01^{\circ} 10^{\prime}-01^{\circ} 33^{\prime} \mathrm{S}$ and $48^{\circ} 38^{\prime}-48^{\circ} 15^{\prime} \mathrm{W}$, and includes the islands of Onças, Jararaca, Jararaquinha, Mirim, Paquetá Açu, and Carnapijó River, which is located west of the islands (Fig. 1). The regional climate is hot and humid, with average annual humidity about $87 \%$. Rain occurs frequently in the afternoon and evening, especially from January to April. The area is characterized by geological units of the Neogene and Quaternary periods, which include Miocene sediments of Barreiras formation and post-Barreiras Quaternary and recent sediments. The Barreiras deposits consist of continental siliciclastic sediments including claystones, sandstones, and conglomerates with poorly consolidated ferruginous sandstones (Rossetti 2001). The eastern margin consists of topographically lower area, and the low clay content in sediments shows that Guajará Bay presents a higher-energy hydrodynamic regime (Gregório \& Mendes 2009).

Several studies involving $\mathrm{Pb}$ concentration and isotopes have been previously conducted in the metropolitan area of Belém. Bollhöfer and Rosman (2000) found an isotope ratio ${ }^{206} \mathrm{~Pb} /{ }^{207} \mathrm{~Pb}$ of 1.15 in aerosols in the Icoaraci district, an industrial district located in the northern sector of Belém. This result was considered an indication of anthropogenic contributions. In addition, Moura et al. (2004) determined ${ }^{206} \mathrm{~Pb} /{ }^{207} \mathrm{~Pb}$ ratios of bottom sediments and soil in three different areas (Fig. 1). Their results showed that in the Maguari Channel, located in the Icoaraci district, the bottom sediments had values between 1.162 and 1.199. In Água Preta Lake, one of the most important potable water supply of Belém, ${ }^{206} \mathrm{~Pb} /{ }^{207} \mathrm{~Pb}$ ratios of 1.166 to 1.176 and between 1.192 and 1.194 were obtained, respectively, in bottom sediments near the urban area and from a non-urbanized area. In between, intermediate ${ }^{206} \mathrm{~Pb} /{ }^{207} \mathrm{~Pb}$ values of 1.187 to 1.188 were determined. In the Aurá landfill area, which is the main waste disposal site of Belém and surrounding areas, the bottom sediments and soil were found to have a low ${ }^{206} \mathrm{~Pb} /{ }^{207} \mathrm{~Pb}$ ratio of 1.145 to 1.174 . Moura et al. (2004) suggested that high isotopic ratios close to 1.20 reflect the isotopic $\mathrm{Pb}$ signature of the natural environment, and that lower isotope ratios indicate anthropogenic contributions related to industrial and urban settlement activity.

Oliveira et al. (2013) found $\mathrm{Pb}$ concentrations of 3 and $5 \mathrm{mg} \mathrm{kg}^{-1}$, and ${ }^{206} \mathrm{~Pb} /{ }^{207} \mathrm{~Pb}$ values from 1.183 to 1.189 in oligochaete and polychaete organisms in sediments from the eastern margin of Guajará Bay, along the Belém waterfront. Bottom sediments sampled at the mouth of the Una Channel in the Bay (also from the eastern margin of the Bay) had a ${ }^{206} \mathrm{~Pb} /{ }^{207} \mathrm{~Pb}$ ratio of 1.167 , revealing the contribution from domestic sewage that was discharged by the channel. At the Miramar petrochemical terminal, also on the Belém waterfront, $\mathrm{a}^{206} \mathrm{~Pb} /{ }^{207} \mathrm{~Pb}$ ratio of 1.188 was obtained; a value possibly related to some incipient impact of the byproducts of oil spreading anthropogenic $\mathrm{Pb}$ throughout the environment. At the mouth of the Tucunduba Channel, which empties 
into Guamá River (southern sector of the city of Belém), bottom sediments showed a ${ }^{206} \mathrm{~Pb} /{ }^{207} \mathrm{~Pb}$ ratio of 1.193 (Fig. 1).

Furthermore, Santos et al. (2012) obtained ${ }^{206} \mathrm{~Pb} /{ }^{207} \mathrm{~Pb}$ ratios in bottom sediments of Guamá River between 1.193 and 1.20 and 1.194 and 1.197, on the left and right margins, respectively. They considered that these geogenic values are not influenced by anthropogenic components. The authors additionally proposed a $\mathrm{Pb}$ background value of $18 \mathrm{mg} \mathrm{kg}^{-1}$ and $\mathrm{a}^{206} \mathrm{~Pb} /{ }^{207} \mathrm{~Pb}$ ratio of 1.196 as a natural reference in the hydrographic system of Belém. Locally, on the right margin of this river, ${ }^{206} \mathrm{~Pb} /{ }^{207} \mathrm{~Pb}$ ratios between 1.186 and 1.192 were observed and pointed to a specific anthropogenic contribution of $\mathrm{Pb}$ from a channel draining the Aurá landfill. On the western margin of Guajará Bay, $\mathrm{Pb}$ levels are higher than $28 \mathrm{mg} \mathrm{kg}^{-1}$, and ${ }^{206} \mathrm{~Pb} /{ }^{207}$ ratios between 1.173 and 1.188 indicate an even higher contribution of anthropogenic sources. The only sample analyzed from the Belém waterfront, on the eastern margin of the Bay, provided the lowest ${ }^{206} \mathrm{~Pb} /{ }^{207}$ ratio value of 1.172 , and contained $37 \mathrm{mg} \mathrm{kg}^{-1}$ of $\mathrm{Pb}$. It is noteworthy that this sample came from the mouth of the Val de Cans Channel (Fig. 1), which also discharges untreated urban wastewater in the bay.

The purpose of this study was to evaluate the effect of human activities on the $\mathrm{Pb}$ trace metal distribution in the estuarine system of the Belém region, by studying the concentration and isotopic signature of $\mathrm{Pb}$ in bottom sediments in two areas: the western margin of Guajará Bay and the Carnapijó River, an area far removed from the influence of Belém metropolitan area. In addition, the study aimed to assess the contribution of suspended matter as means of transporting anthropogenic-related $\mathrm{Pb}$ in Guajará Bay, and to ascertain whether the contents and isotopic composition of $\mathrm{Pb}$ previously proposed as geogenic $\mathrm{Pb}$ (Santos et al. 2012) can be considered as a background for the whole river system of Belém.

\section{MATERIALS AND METHODS}

A total number of 13 bottom sediment samples were collected using a Russian Peat Borer-type core drill (Souza et al. 2008), and 1 sample (sample B5) was collected using a Petersen dredge. These 2 types of samples corresponded respectively to 10 and $5 \mathrm{~cm}$ of the surface layer of bottom sediments. Seven points were sampled on the western margin of Guajará Bay (samples 1A-7A), 6 in Carnapijó River (samples B2-B10) and 1 sample (sample B1) at the confluence of Acará River, Carnapijó River and Guajará Bay. These samples were initially stored in a Ziploc bag, before being dried at $50^{\circ} \mathrm{C}$ and then disaggregated in an agate mortar. A thin fraction (silt + clay) was separated from the samples by classical wet sieving method using a stainless steel sieve of $63 \mu \mathrm{m}$ (250 mesh).

Two samples of suspended matter were collected in a 100 L container from Guajará Bay, one from the margin of the Belém waterfront (sample MS4) and the other from the western side of the Bay (sample MS3), and allowed to stand for a few days. The water was then filtered using $45 \mu \mathrm{m}$ cellulose filter paper to determine the presence of suspended matter. The material deposited on the bottom of the container (approximately 0.3 and $0.5 \mathrm{~g}$ for MS3 and MS4, respectively) was transferred to a Teflon container and dried in a plate heater at $40^{\circ} \mathrm{C}$. Only the isotopic composition of $\mathrm{Pb}$ was determined from these samples.

To calculate the percentage of organic matter in the sediments, organic carbon (OC) was determined by oxidizing $300 \mathrm{mg}$ of the sample with $1 \mathrm{~N}$ potassium dichromate $\left(\mathrm{K}_{2} \mathrm{Cr}_{2} \mathrm{O}_{7}\right)$ in an acid media $\left(\mathrm{H}_{2} \mathrm{SO}_{4}+\mathrm{H}_{3} \mathrm{PO}_{4}\right)$ at $100^{\circ} \mathrm{C}$ and, subsequently, performing titration with ferrous ammonium sulfate, using the method proposed by Loring \& Rantala (1992).

The total concentrations of $\mathrm{Pb}, \mathrm{Al}$ and $\mathrm{Fe}$ in the fine fraction of bottom sediments were then determined in a commercial laboratory. The standard procedure used was to fully dissolve $0.25 \mathrm{~g}$ of a sample using a combination of concentrated acids $\mathrm{HF}-\mathrm{HNO}_{3}-\mathrm{HClO}_{4}-\mathrm{HCl}$, for subsequent analysis by ICP-MS mass spectrometry. The concentration of exchangeable $\mathrm{Pb}$ in the fine fraction of bottom sediments was also determined in the same laboratory, using a standard procedure in which $0.5 \mathrm{~g}$ of a sample was leached with a combination of acid at a ratio of $1: 3 \mathrm{HNO}_{3}-\mathrm{HCl}$ (Aqua Regia), and subsequently analyzed with ICP-MS mass spectrometry. During chemical analysis, the analytical quality control procedure used within the laboratory included the analysis of samples in duplicate and against STD OREAS 24P and STD OREAS 45PA reference materials (in-house standard). Details on the procedures are available online on the laboratory's website (www.acmelab.com).

The isotopic compositions were then determined in the Isotope Geology Laboratory (Pará-Iso) at the Geosciences Institute of the Universidade Federal do Pará, according to the experimental procedure described by Lafon et al. (1993) and Santos et al. (2012). One gram of each sediment sample was leached with $3 \mathrm{~mL}$ of $\mathrm{HNO}_{3} 5 \mathrm{~N}$ and stirred during 24 hours, and then leached using $\mathrm{HBr} 8 \mathrm{~N}$. Chromatographic separation of $\mathrm{Pb}$ was performed in Teflon micro columns filled with BioRad Dowex AG1-X8 resin, using a $200-$ 400 mesh, in $\mathrm{HBr} 0.5 \mathrm{~N}$ medium. The same procedure was used for the samples of suspended matter.

The isotopic composition of $\mathrm{Pb}$ in some of the samples was determined using mass spectrometry with thermal ionization (TIMS), and for others it was determined using mass 
spectrometry with Inductively Coupled Plasma (ICP-MS). For the TIMS analysis, purified $\mathrm{Pb}$ was concentrated with $\mathrm{H}_{3} \mathrm{PO}_{4}$ and deposited with silica gel on a rhenium filament. Isotopic analyses were performed in a static mode using a Finnigan MAT 262 model mass spectrometer equipped with multicollectors. ${ }^{206} \mathrm{~Pb} /{ }^{207} \mathrm{~Pb}$ ratios were corrected by a discrimination factor of $0.12 \pm 0.03 \%$ per atomic mass unit, determined from repeated analysis of the reference material NBS 982 (equal atoms). For ICP-MS analysis, the purified $\mathrm{Pb}$ was dissolved in $2 \mathrm{~mL}$ of $\mathrm{HNO}_{3} 3 \%+\mathrm{Tl}$ (thallium) $50 \mathrm{ppb}$. Isotopic analysis was then performed using a Thermo-Finnigan Neptune model mass spectrometer with multicollectors. In this mass spectrometer, the ${ }^{205} \mathrm{Tl} /{ }^{203} \mathrm{Tl}$ ratio was used to correct the isotopic ratios of $\mathrm{Pb}$, from mass fractionation effects according to the exponential law (Platzner et al. 2001). Accuracy control of the analyses was performed with repeated analysis of NBS 981 reference material (common lead), and the multi-element Tune-up Reference Solution for Neptune furnished by
Thermo Fisher Scientific. The total blanks used to estimate the level of contamination introduced during analytical procedures were always less than $0.1 \%$ of the $\mathrm{Pb}$ amount of the samples and were therefore negligible.

\section{RESULTS}

Detailed information relating to the particle size characterization with Shepard (1954) and Pejrup (1988) diagrams and the mineralogical composition of the clay fraction can be found in Oliveira et al. (in press).

The bottom sediments samples are composed mainly of sand and silty-sand, indicating high hydrodynamics depositional conditions. The mineralogical composition of the clay fraction of the bottom sediments showed a predominance of kaolinite, smectite, and illite clayminerals, similar to the composition described in previous studies (Santos et al. 2012).

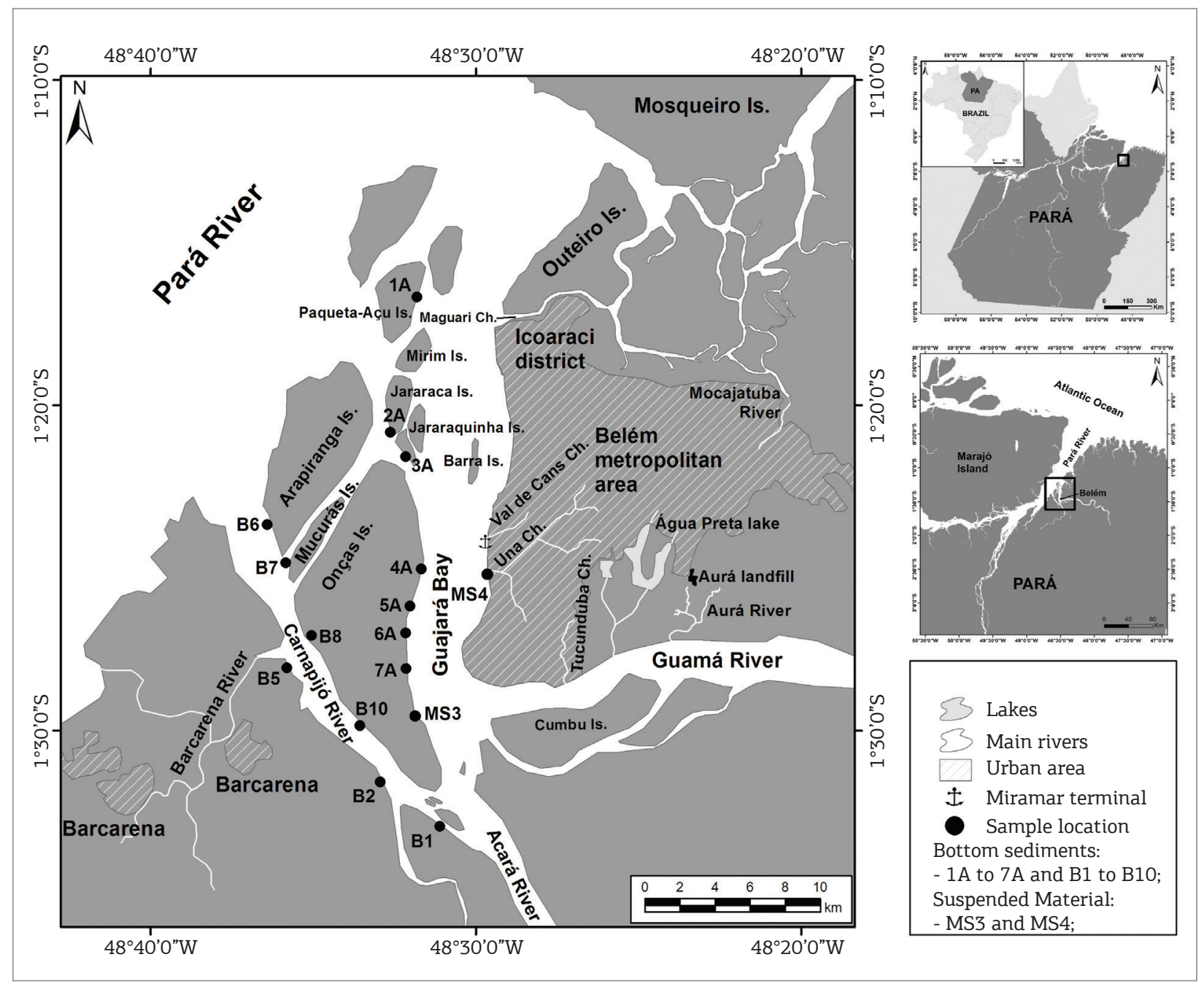

Figure 1. Map of the study area showing the sample location (modified from Pinheiro 1987). 


\section{$\mathrm{Pb}, \mathrm{Al}, \mathrm{Fe}$ and organic matter content in the sediments}

The total concentration of $\mathrm{Pb}$ in samples from the western margin of Guajará Bay ranged from 17.1 to $32.4 \mathrm{mg} \mathrm{kg}^{-1}$, with higher concentrations in the samples taken from the Paquetá Açu island (1A) and Onças island (4A and 6A) (Tab. 1). Concentrations in the sediments of Carnapijó River were slightly more homogeneous, ranging from 14.3 to $23.6 \mathrm{mg}$ $\mathrm{kg}^{-1}$, which overlap the range of the samples obtained from the Bay, but with lower values. The sample from the confluence of Acará River (B1) had a Pb content of $26 \mathrm{mg} \mathrm{kg}^{-1}$, a value that was within the range of samples from the western margin of the Bay (Fig. 2).

Table 1. Total concentrations and exchangeable $\mathrm{Pb}$ $\left(\mathrm{mg} \mathrm{kg}^{-1}\right)$, total abundances (weight \%) of $\mathrm{Al}, \mathrm{Fe}$, and organic matter, determined in the fine fraction of bottom sediments from the western margin of Guajará Bay and Carnapijó River.

\begin{tabular}{|c|c|c|c|c|c|}
\hline Sample & $\mathrm{Pb}_{\text {tot. }}$ & $\mathrm{Pb}_{\text {ex. }}$ & Al & $\mathbf{F e}$ & OM \\
\hline \multicolumn{6}{|c|}{ Western bank of Guajará Bay } \\
\hline $\begin{array}{l}\text { 1A (Paquetá Açu } \\
\text { Island) }\end{array}$ & 27.3 & 21.4 & 5.0 & 3.6 & 3.0 \\
\hline 2A (Jararaca Island) & 25.6 & n.d. & 4.4 & 3.2 & 5.2 \\
\hline $\begin{array}{l}\text { 3A (Jararaquinha } \\
\text { Island) }\end{array}$ & 19.1 & 11.9 & 3.6 & 2.1 & 2.3 \\
\hline 4A (Onças Island) & 29.4 & 16.6 & 7.0 & 3.4 & 5.0 \\
\hline 5A (Onças Island) & 26.2 & 18.1 & 4.8 & 3.5 & 1.8 \\
\hline 6A (Onças Island) & 32.4 & 18.5 & 6.8 & 4.0 & 5.1 \\
\hline 7A (Onças Island ) & 17.1 & 9.9 & 2.9 & 1.7 & 4.5 \\
\hline Mean & 25.3 & 16.1 & 4.9 & 3.1 & 3.9 \\
\hline Standard deviation & 5.4 & 4.3 & 1.5 & 0.8 & 1.4 \\
\hline \multicolumn{6}{|l|}{ Carnapijó River } \\
\hline B6 (Arapiranga Island) & 15.6 & 11.0 & 3.8 & 2.8 & 0.9 \\
\hline B7 (Mucurás Island) & 22.0 & 16.3 & 4.9 & 3.5 & 1.3 \\
\hline B8 (Onças Island ) & 23.6 & 16.8 & 6.2 & 4.2 & 1.0 \\
\hline $\begin{array}{l}\text { B5 (Confluence of } \\
\text { river Barcarena) }\end{array}$ & 14.3 & 9.2 & 3.0 & 2.3 & 0.8 \\
\hline B10 (Onças Island) & 19.9 & 12.8 & 4.4 & 3.1 & 0.9 \\
\hline B2 (Western bank) & 22.2 & 14.9 & 3.6 & 3.4 & 1.2 \\
\hline Mean & 19.3 & 13.5 & 4.3 & 3.2 & 1.0 \\
\hline Standard deviation & 3.7 & 3.0 & 1.1 & 0.6 & 0.2 \\
\hline $\begin{array}{l}\text { B1 (Confluence of } \\
\text { river Acará) }\end{array}$ & 26.1 & 19.7 & 7.1 & 6.0 & 1.5 \\
\hline
\end{tabular}

tot.: total concentrations; ex.: exchangeable; OM: organic matter.
The $\mathrm{Pb}$ contents determined in the exchangeable fraction of samples from the western margin of Guajará Bay varied from 9.9 to $21.4 \mathrm{mg} \mathrm{kg}^{-1}$, while samples from Carnapijó River also varied from 9.2 to $16.3 \mathrm{mg} \mathrm{kg}^{-1}$ (Tab. 1). Again, the sample at the confluence of Acará River (B1) had a Pb content of $19.7 \mathrm{mg} \mathrm{kg}^{-1}$, a value within the range from samples from the western margin of the bay (Fig. 2). Overall, proportionality between the total and exchangeable $\mathrm{Pb}$ concentrations was observed $\left(1.3<\mathrm{Pb}_{\text {total }} / \mathrm{Pb}_{\text {exchangeable }}<1.8\right)$.

The samples from the western margin of Guajará Bay had a high organic matter $(\mathrm{OM})$ content, with values of $1.8 \%$ for the sample on the Onças island (5A) and 5.2\% for the sample on Jararaquinha island (2A). The samples from Carnapijó River and those taken at the confluence of Acará River showed lower levels, from $0.8-1.3$ and $1.5 \%$, respectively. There were no significant differences in the $\mathrm{Al}$ and $\mathrm{Fe}$ contents between the two sectors studied, with respective mean values of 4.9 and $3.1 \%$ for samples from the western

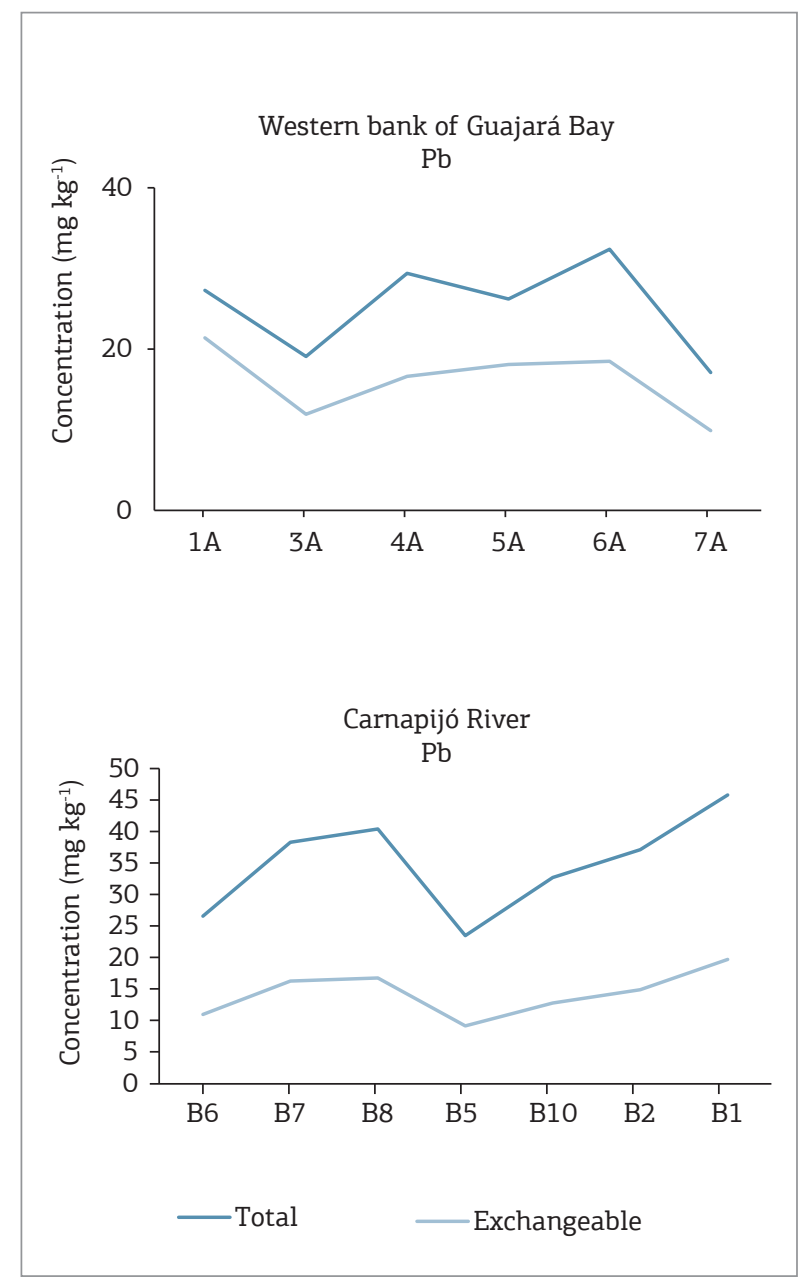

Figure 2. Diagram of the distribution of the total and exchangeable $\mathrm{Pb}$ content in bottom sediments. (A) Western margin of Guajará Bay, and (B) Carnapijó River. 
margin of Guajará Bay, and 4.3 and 3.2\% for sediments from Carnapijó River. The sample from the confluence of Acará River showed the highest values of all samples, at 7.1 and $6.0 \%$, respectively.

The correlation coefficients between the $\mathrm{Pb}$ content and the $\mathrm{Al}, \mathrm{Fe}$ and $\mathrm{OM}$ contents were determined using the Estatistica ${ }^{\circledR}$ program. On the western margin of Guajará Bay, $\mathrm{Pb}$ showed an excellent correlation with $\mathrm{Al}$ and $\mathrm{Fe}$; however, no correlation was observed with OM (Tab. 2). The Carnapijó River samples, showed a very strong correlation with $\mathrm{Al}$ and

Table 2. Correlation matrix between the total $\mathrm{Pb}$ and $\mathrm{Al}, \mathrm{Fe}$, and organic matter $(\mathrm{OM})$ in sediments from the western margin of Guajará Bay. Values in bold type emphasize strong correlation (correlation coefficient $>0.80$ ).

\begin{tabular}{l|c|c|c|c}
\hline & $\mathbf{P b}$ & $\mathbf{A l}$ & $\mathbf{F e}$ & OM \\
\hline $\mathrm{Pb}$ & 1.00 & & & \\
\hline $\mathrm{Al}$ & $\mathbf{0 . 9 3}$ & 1.00 & & \\
\hline $\mathrm{Fe}$ & $\mathbf{0 . 9 7}$ & $\mathbf{0 . 8 3}$ & 1.00 & \\
\hline $\mathrm{OM}$ & 0.31 & 0.38 & 0.14 & 1.00 \\
\hline
\end{tabular}

OM: organic matter.
Fe and a good correlation with OM (Tab. 3). When the B1 sample was excluded from the calculation, the correlation with Fe became even greater (Tab. 3).

\section{$\mathrm{Pb}$ isotopic data of bottom sediments and suspended matter}

Analyses of the $\mathrm{Pb}$ isotopic compositions from the samples of bottom sediments and two samples of suspended matter are displayed in Table 4.

Table 3. Correlation matrix between the total $\mathrm{Pb}$ and $\mathrm{Al}$, $\mathrm{Fe}$, and $\mathrm{OM}$ in sediments from Carnapijó River. The values in parentheses show the correlation coefficient excluding the B1 sample obtained from the confluence of Carnapijó River and Guajará Bay. Values in bold type emphasize strong correlation (correlation coefficient $>0.80$ ).

\begin{tabular}{l|c|c|c|c}
\hline & $\mathbf{P b}$ & $\mathbf{A l}$ & $\mathbf{F e}$ & $\mathbf{O M}$ \\
\hline $\mathrm{Pb}$ & 1.00 & & & \\
\hline $\mathrm{Al}$ & $\mathbf{0 . 8 4}(0.75)$ & 1.00 & & \\
\hline $\mathrm{Fe}$ & $\mathbf{0 . 8 8}(\mathbf{0 . 9 4 )}$ & $\mathbf{0 . 9 3}(\mathbf{0 . 9 0 )}$ & 1.00 & \\
\hline $\mathrm{OM}$ & $\mathbf{0 . 8 2}(0.72)$ & $0.66(0.31)$ & $\mathbf{0 . 8 2}(0.57)$ & 1.00 \\
\hline \multicolumn{5}{l}{$\mathrm{OM}$ organic matter. }
\end{tabular}

Table 4. $\mathrm{Pb}$ isotopic ratios determined by leaching of the fine fraction of sediments from the western margin of Guajará Bay and Carnapijó River, and in suspended matter from Guajará Bay.

\begin{tabular}{|c|c|c|c|c|c|c|c|c|c|c|}
\hline Sample & $\mathrm{Pb}_{\text {tot. }}$ & ${ }^{206} \mathrm{~Pb} /{ }^{204} \mathrm{~Pb}$ & $2 \sigma$ & ${ }^{207} \mathrm{~Pb} /{ }^{204} \mathrm{~Pb}$ & $2 \sigma$ & ${ }^{208} \mathrm{~Pb} /{ }^{204} \mathrm{~Pb}$ & $2 \sigma$ & ${ }^{208} \mathrm{~Pb} /{ }^{206} \mathrm{~Pb}$ & ${ }^{206} \mathrm{~Pb} /{ }^{207} \mathrm{~Pb}$ & $2 s$ \\
\hline \multicolumn{11}{|c|}{ Western bank of Guajará Bay (Bottom sediments) } \\
\hline $1 \mathrm{~A}$ & 27.3 & 18.607 & 0.015 & 15.654 & 0.019 & 38.567 & 0.062 & 2.073 & 1.189 & 0.00001 \\
\hline $2 \mathrm{~A}$ & 25.6 & 18.515 & 0.015 & 15.684 & 0.019 & 38.500 & 0.061 & 2.079 & 1.181 & 0.00002 \\
\hline $3 \mathrm{~A}$ & 19.1 & 18.649 & 0.015 & 15.674 & 0.019 & 38.693 & 0.062 & 2.075 & 1.190 & 0.00005 \\
\hline $4 \mathrm{~A}$ & 29.4 & 18.728 & 0.015 & 15.695 & 0.019 & 38.832 & 0.063 & 2.074 & 1.193 & 0.00002 \\
\hline $5 \mathrm{~A}$ & 26.2 & 18.653 & 0.016 & 15.685 & 0.019 & 38.696 & 0.062 & 2.075 & 1.189 & 0.00003 \\
\hline $6 \mathrm{~A}$ & 32.4 & 18.835 & 0.016 & 15.752 & 0.019 & 39.093 & 0.064 & 2.076 & 1.196 & 0.00003 \\
\hline $7 \mathrm{~A}$ & 17.1 & 18.465 & 0.015 & 15.654 & 0.019 & 38.479 & 0.062 & 2.084 & 1.180 & 0.00004 \\
\hline \multicolumn{11}{|c|}{ Suspended matter (Guajará bay) } \\
\hline MS3 & -- & 18.404 & 0.0003 & 15.678 & 0.0003 & 38.390 & 0.001 & 2.086 & 1.174 & 0.00001 \\
\hline MS4 & -- & 18.589 & 0.0006 & 15.649 & 0.0005 & 38.599 & 0.0001 & 2.076 & 1.188 & 0.00002 \\
\hline \multicolumn{11}{|c|}{ Carnapijó river (Bottom sediments) } \\
\hline B6 & 15.6 & 18.755 & 0.023 & 15.662 & 0.028 & 38.792 & 0.093 & 2.068 & 1.197 & 0.00072 \\
\hline B7 & 22.0 & 18.683 & 0.003 & 15.620 & 0.003 & 38.705 & 0.007 & 2.072 & 1.196 & 0.00001 \\
\hline B8 & 23.6 & 18.777 & 0.001 & 15.662 & 0.001 & 38.834 & 0.004 & 2.068 & 1.199 & 0.00002 \\
\hline B5 & 14.3 & 18.629 & 0.022 & 15.668 & 0.028 & 38.700 & 0.093 & 2.077 & 1.189 & 0.00072 \\
\hline B10 & 19.9 & 18.726 & 0.003 & 15.652 & 0.003 & 38.761 & 0.006 & 2.070 & 1.196 & 0.00003 \\
\hline B2 & 22.2 & 18.687 & 0.022 & 15.672 & 0.028 & 38.748 & 0.093 & 2.074 & 1.192 & 0.00072 \\
\hline B1 & 26.1 & 18.825 & 0.030 & 15.688 & 0.032 & 38.900 & 0.102 & 2.066 & 1.200 & 0.00073 \\
\hline
\end{tabular}


The ${ }^{206} \mathrm{~Pb} /{ }^{207} \mathrm{~Pb}$ isotopic ratios of bottom sediments from the western margin of Guajará Bay varied from 1.180 to 1.196, and the highest values were found in two samples taken from the Onças island (4A and 6A), with ratios of 1.193 and 1.196 and high $\mathrm{Pb}$ concentrations. However, the values of ${ }^{206} \mathrm{~Pb} /{ }^{207} \mathrm{~Pb}$ ratios observed in samples from the Paquetá Açu (1A), Jararaca (2A), Jararaquinha $(3 \mathrm{~A})$ and Onças $(5 \mathrm{~A}$ and $7 \mathrm{~A})$ islands were significantly lower, with low concentrations of $\mathrm{Pb}$. In Carnapijó River, ${ }^{206} \mathrm{~Pb} /{ }^{207} \mathrm{~Pb}$ ratios of 1.189 to 1.200 were obtained, with low concentrations of $\mathrm{Pb}$. In addition, sample B5 had the lowest $\mathrm{Pb}$ isotope ratio. The suspended matter samples from margin of the Onças island (MS3) and from the mouth of the Una Canal (MS4) had ${ }^{206} \mathrm{~Pb} /{ }^{207} \mathrm{~Pb}$ ratios of 1.174 and 1.188 , respectively.

In the diagram showing ${ }^{206} \mathrm{~Pb} /{ }^{207} \mathrm{~Pb}$ ratios versus the total concentrations of $\mathrm{Pb}$ (Fig. 3), including the data by Santos et al. (2012), and a sample from Mocajatuba River, which represents sediments with the lowest isotope ratio and highest $\mathrm{Pb}$ content in the Belém river system $\left({ }^{206} \mathrm{~Pb} /{ }^{207} \mathrm{~Pb}=\right.$ 1.162; [Pb] = $89 \mathrm{mg} \mathrm{kg}^{-1}$; Moura et al. 2004), the Carnapijó River bottom sediments define a relatively homogeneous area. In addition, they have high isotopic ratios that overlap with the field of samples from Guamá River obtained by Santos et al. (2012). The bottom sediments from the western margin of Guajará Bay are more dispersed and define a wider field, with lower ${ }^{206} \mathrm{~Pb} /{ }^{207} \mathrm{~Pb}$ ratios and higher or equal $\mathrm{Pb}$ contents than those of the previous field samples and partially overlap that defined by the bottom sediment samples of Santos et al. (2012). However, unlike the samples analyzed by Santos et al. (2012), the points do not show a decreasing trend in the isotope ratios, with an increase in the Pb content (Fig. 3).

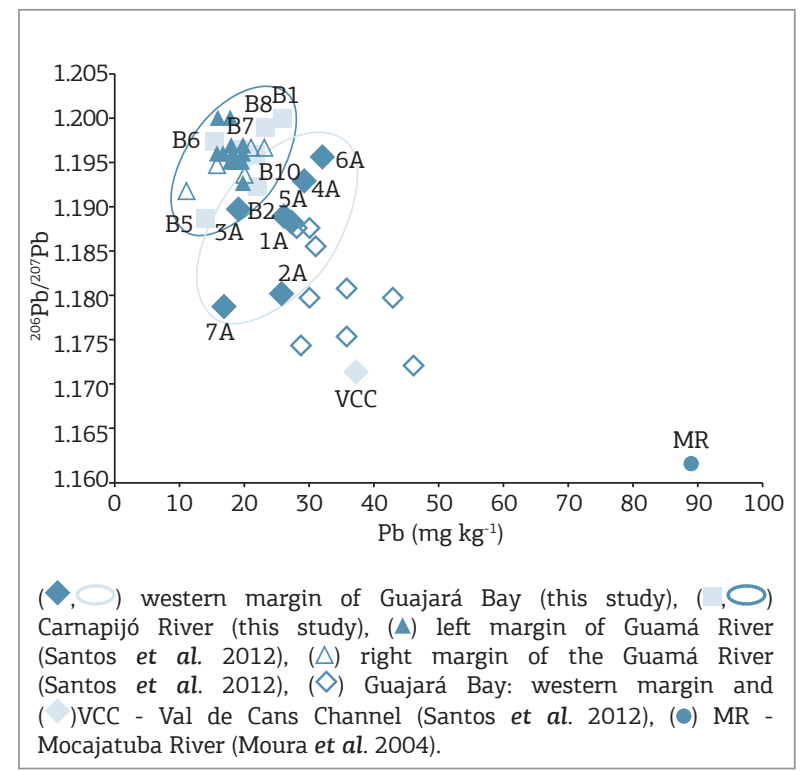

Figure 3. Diagram showing $\mathrm{Pb}\left(\mathrm{mg} \mathrm{kg}^{-1}\right)$ versus ${ }^{206} \mathrm{~Pb} /{ }^{207} \mathrm{~Pb}$ of bottom sediments.

\section{DISCUSSION}

\section{Relationship between $\mathrm{Pb}$ and levels of $\mathrm{Al}, \mathrm{Fe}$, and $\mathrm{OM}$}

The correlation matrices showed that there was a significant correlation between $\mathrm{Pb}$ and $\mathrm{Al}$ and Fe elements on the western margin of Guajará Bay and Carnapijó River, which would suggest that $\mathrm{Pb}$ is associated with aluminosilicate minerals (clays) and oxides-Fe hydroxides as already demonstrated in previous studies (Saraiva 2007, Nascimento 2007). The absence of a strong correlation between $\mathrm{Pb}$ and OM can be explained by the fact that the efficiency of OM in adsorbing chemical compounds essentially depends on its complexing properties (Lima et al. 2004). In this respect, it is possible that the existing $\mathrm{OM}$ in most of the sediments from the western margin of Guajará Bay and Carnapijó River lacks sufficient complexing properties to fix $\mathrm{Pb}$, and may therefore consist purely of organic plant matter.

\section{Evaluation of anthropogenic $\mathrm{Pb}$ contribution}

The isotopic data obtained in this study shown significant variations in the isotopic compositions of the Guajará Bay samples. Some samples had low values, which indicated an anthropogenic contribution. These data coincide slightly with the isotopic composition determined by Santos et al. (2012), although a similar trending correlation in the increase of the $\mathrm{Pb}$ content was not found. Overall, the isotopic signatures suggest an anthropogenic $\mathrm{Pb}$ contribution, but the values are not accompanied by a significant increase in $\mathrm{Pb}$ contents.

In Carnapijó River, the isotopic composition values of $\mathrm{Pb}$ are higher, and within the value levels found in Guamá River, particularly on the left margin. The average ${ }^{206} \mathrm{~Pb} /{ }^{207} \mathrm{~Pb}$ ratio is $1.196 \pm 0.004$ for Carnapijó River, similar to the value observed in the left margin of the Guamá $(1.196 \pm 0.002$, Santos et al. 2012), but different from the average value for the western margin of Guajará Bay (1.188 \pm 0.006$)$, despite the averages being close and within the error. There was no evidence of an anthropogenic influence in this sector of the Belém hydrographic system, which is located faraway from the urban center. The B5 sample, which was taken from the confluence of Barcarena River, has a slightly lower value. This may be related to its proximity to the mouth of Barcarena River, which drains the urban and industrial hub of the city of Barcarena. The B1 sample from the confluence of Acará River was obtained at the furthest point of all samples from the city of Belém, and has a higher ${ }^{206} \mathrm{~Pb} /{ }^{207} \mathrm{~Pb}$ ratio value of 1.20 , which is compatible with having a purely geogenic origin of $\mathrm{Pb}$. 


\section{Criteria and limitations for the use of the concentration and isotopic signature of $\mathrm{Pb}$ in identifying $\mathrm{Pb}$ contamination}

\section{Sampling modes}

The results obtained on our samples from the western margin of Guajará Bay differ from previous results for the same part of the Bay. Even when there were a partial overlapping of the ${ }^{206} \mathrm{~Pb} /{ }^{207} \mathrm{~Pb}$ isotope range, the isotopic composition ${ }^{206} \mathrm{~Pb} /{ }^{207} \mathrm{~Pb}$ of the samples by Santos et al. (2012) showed lower values $\left(1.172<{ }^{206} \mathrm{~Pb} /{ }^{207} \mathrm{~Pb}<1.188\right)$, which were not evident in our results $\left(1.180<{ }^{206} \mathrm{~Pb} /{ }^{207} \mathrm{~Pb}<1.196\right)$ (Fig. 3). Furthermore, there was no evidence of a clear relationship between the increased $\mathrm{Pb}$ content and the decreased isotope ratio, unlike the evidence provided by Santos et al. (2012). It is considered that this difference in behavior may result from the sampling mode. Santos et al. (2012) used a Petersen dredge, in which a surface layer of $5 \mathrm{~cm}$ of the bottom sediments is collected. Our study established the isotopic signatures using the top layer of $10 \mathrm{~cm}$ from a core of bottom sediments, which therefore corresponded to a different time period of deposition. Based on an approximate rate of sediment deposition of $0.7 \mathrm{~cm}_{\text {year }}{ }^{-1}$ for Guajará Bay (Dias et al. 2010; Santos et al. 2012, Oliveira et al. in press), the $10 \mathrm{~cm}$ analysis of the core corresponds to a period of 16 to 18 years of sedimentation, while the sampling by Santos et al. (2012) corresponds to a period of only 8 to 9 years. This difference may justify the less anthropogenic signature found in this study, as the population growth of the city of Belém has accelerated over the past 10 years (Carvalho 2012). The lowest isotope ratio in the sediments from Carnapijó River was found in sample B5, which was the only sample collected in this area using a Petersen dredge. Therefore, this could also reflect the differences in the sampling time rather than any anthropogenic influence from the Barcarena city.

\section{Total and partial concentration of $\mathrm{Pb}$ (exchangeable)}

The anthropogenic $\mathrm{Pb}$ component is preferably located in the exchangeable fraction of bottom sediments removed by acid leaching, while geogenic $\mathrm{Pb}$ is located in the structure of minerals (mainly silicate minerals), and is obtained by total dissolution of the sample (Bur et al. 2009). In studies involving $\mathrm{Pb}$ and its isotopic signature, correlations have been established using both the total concentration (Ferrand et al. 1999, Bindler et al. 2001, Moraes et al. 2004, Miller et al. 2007, Gioia et al. 2006, Dong et al. 2010) and the exchangeable $\mathrm{Pb}$ fraction (Bird et al. 2010; Gioia et al. 2006). For the hydrographic system of Belém, results have been presented using either the total $\mathrm{Pb}$ (Santos et al. 2012) or exchangeable $\mathrm{Pb}$ concentrations (Moura et al. 2004). In the $\mathrm{Pb}$ content vs. isotopic signature diagrams, exchangeable $\mathrm{Pb}$ should be normally used because the isotopic signatures are obtained by acid leaching, which preferentially remove the anthropogenic lead component. However, there is a relationship between exchangeable (leachate) and total $\mathrm{Pb}$ concentrations, considering that the geogenic $\mathrm{Pb}$ value content must remain constant and the total concentration varies only due to the increase in the anthropogenic contribution. Ettler et al. (2004) suggested using the $\mathrm{Pb} / \mathrm{Al}$ ratio instead of $\mathrm{Pb}$ contents to identify the presence of anthropogenic $\mathrm{Pb}$. It is evident that in the ${ }^{206} \mathrm{~Pb} /{ }^{207} \mathrm{~Pb}$ versus $\mathrm{Pb} / \mathrm{Al}$ diagram, there is a clear tendency of the ${ }^{206} \mathrm{~Pb} /{ }^{207} \mathrm{~Pb}$ ratio to decrease as the $\mathrm{Pb} / \mathrm{Al}$ ratio increases, with respectively lower and higher values for the Guajará Bay samples than the samples from Carnapijó River (Fig. 4). The sample taken from the Acará River confluence, despite having a $\mathrm{Pb}$ content similar to that of the more concentrated samples from Guajará Bay, has the lowest $\mathrm{Pb} / \mathrm{Al}$ ratio and the highest ${ }^{206} \mathrm{~Pb} /{ }^{207} \mathrm{~Pb}$ ratio $(1.20)$. This suggests that the $\mathrm{Pb} / \mathrm{Al}$ ratio is an appropriate parameter to be considered with the isotopic signature of $\mathrm{Pb}$, for use in indicating an anthropogenic contribution. The B2 sample has a distinct behavior, and it stands out because it has the highest $\mathrm{Pb} / \mathrm{Al}$ ratio and a high isotopic signature $\left({ }^{206} \mathrm{~Pb} /{ }^{207} \mathrm{~Pb}\right.$ $=1.192)$. However, the fact that this sample has a much higher percentage of sand (>95\%) than all other samples (Oliveira et al. in press) may have caused the increase in the $\mathrm{Pb} / \mathrm{Al}$ ratio in relation to the low $\mathrm{Al}$ content, and not because of the high $\mathrm{Pb}$ content.

\section{Variation in the background for \\ $\mathrm{Pb}$ content and isotopic signature}

The background value for the $\mathrm{Pb}$ concentration of bottom sediments is difficult to determine, especially in estuarine systems with fairly complex hydrodynamics. This undermines the ability to obtain a reliable determination of

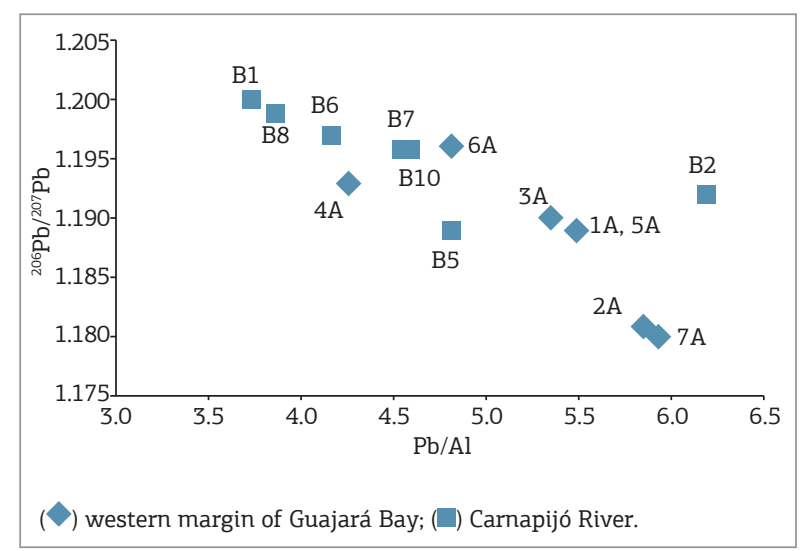

Figure 4. ${ }^{206} \mathrm{~Pb} /{ }^{207} \mathrm{~Pb}$ versus $\mathrm{Pb}_{\text {total }}\left(\mathrm{mg} \mathrm{kg}^{-1}\right) / \mathrm{Al}$ (weight \%) diagram of bottom sediments; 
anthropogenic contributions, as contamination levels (Geoaccumulation Index, Enrichment Factor etc.) depend on the choice of a reference value for natural $\mathrm{Pb}$ (such as the average continental crust value or the natural local value). A background value about $18 \mathrm{mg} \mathrm{kg}^{-1}$ for total $\mathrm{Pb}$ was proposed by Santos et al. (2012) for the Belém hydrographic system with a corresponding ${ }^{206} \mathrm{~Pb} /{ }^{207} \mathrm{~Pb}$ isotopic signature of 1.196 . It is considered that the average total $\mathrm{Pb}$ content of $19.3 \pm 3.7 \mathrm{mg} \mathrm{kg}^{-1}\left(20.5 \pm 4.3 \mathrm{mg} \mathrm{kg}^{-1}\right.$, when including the $\mathrm{B} 1$ sample from the confluence with Acará River) and the average ${ }^{206} \mathrm{~Pb} /{ }^{207} \mathrm{~Pb}$ ratio of $1.196 \pm 0.004$ obtained for Carnapijó River also reflect the geogenic background.

\section{Sources and transport of anthropogenic $\mathrm{Pb}$}

Previous studies have determined that the accumulation of anthropogenic $\mathrm{Pb}$, which is found in natural environments such as lakes, peat bogs, and oceanic waters, is linked to industrial atmospheric sources rather than to the dumping of domestic sewage and industrial waste (Komarék et al. 2008, Bollhöfer \& Rosman 2000). However, the transport and accumulation of anthropogenic $\mathrm{Pb}$ in estuarine environments occurs mainly by sorption to suspended matter (Helland et al. 2002, Callender 2011).

Bollhöfer and Rosman (2000) determined an isotope ${ }^{206} \mathrm{~Pb} /{ }^{207} \mathrm{~Pb}$ ratio of 1.15 in particulate matter (aerosols) found in the industrial district of Icoaraci, in the northern sector of Belém. It has also been considered that the anthropogenic $\mathrm{Pb}$ contribution in relation to atmospheric transport could explain the isotopic signatures of bottom sediments on the western margin of Guajará Bay. However, Santos et al., (2012) dismissed such a hypothesis, and suggested suspended matter to be the main vehicle for $\mathrm{Pb}$ transport to the western margin of the Bay.

In ${ }^{206} \mathrm{~Pb} /{ }^{207} \mathrm{~Pb}$ versus ${ }^{206} \mathrm{~Pb} /{ }^{204} \mathrm{~Pb}$ and ${ }^{208} \mathrm{~Pb} /{ }^{206} \mathrm{~Pb}$ versus ${ }^{206} \mathrm{~Pb} /{ }^{207} \mathrm{~Pb}$ diagrams (Figs. 5 and 6 , respectively), the isotopic signatures of the two samples of suspended matter from the Belém waterfront were inserted, in addition to those of bottom sediments from Carnapijó River and western margin Guajará Bay (this study). Also inserted were those from bottom sediments obtained from the left and right margins of Guamá River (Santos et al. 2012), three samples from the Belém waterfront (Santos et al. 2012; Oliveira et al. 2013) and the values from aerosols in Icoaraci district (Bollhöfer $\&$ Rosman 2000). All samples show a linear arrangement, which is compatible with binary mixing between a geogenic pole, as marked by samples from Carnapijó and Guamá Rivers $\left({ }^{206} \mathrm{~Pb} /{ }^{207} \mathrm{~Pb}_{\text {average }}=1.196\right)$, and an anthropogenic pole, marked by the isotopic signature from aerosols obtained in the industrial district. The two suspended matter samples showed distinct isotopic compositions of geogenic $\mathrm{Pb}$, particularly in the case of the sample taken from the western margin of the Bay $\left({ }^{206} \mathrm{~Pb} /{ }^{207} \mathrm{~Pb}=1.174\right)$. This sample was obtained close to that of the bottom sediment sample, which had a more anthropogenic isotopic signature of ${ }^{206} \mathrm{~Pb} /{ }^{207} \mathrm{~Pb}=1.170$ (Santos et al. 2012).

The $\mathrm{Pb}$ isotopic signatures point to the southern sector where the Bay is narrower as the area from the western margin of the Bay most affected by the anthropogenic contribution. The main drivers of the deposition and dispersion of sediments in Guajará Bay are the topography, river inflow, and tidal currents (Gregório \& Mendes 2009). These authors also identified that the hydrodynamic regime of Guajará Bay is controlled by a flooding stream at the eastern margin of the Bay, and an ebb on the western margin. The suspended matter is thus transported during the flood and ebb tide from the Belém waterfront on the eastern margin to the western margin, and the water discharge from Guamá River promotes the transport in that direction (Fig. 7). This hydrodynamic behavior would thus be responsible for increasing the anthropic influence along the entire length of the Bay, not only on the Belém waterfront, in relation to transport by suspended particulate matter.

The fact that the samples from the Belém waterfront (Una and Val de Cans channels; Santos et al. 2012; Oliveira et al. 2013) and aerosols (Bolhöfer \& Rosman 2000) plot on the same linear trend in both $\mathrm{Pb}$ isotopic diagrams (Figs. 5 and 6) indicates that the isotopic signature of the contaminant end-member of industrial aerosols and urban wastewaters is probably similar. In addition, Petroleum byproducts like gasoline or used motor oil may also be involved as

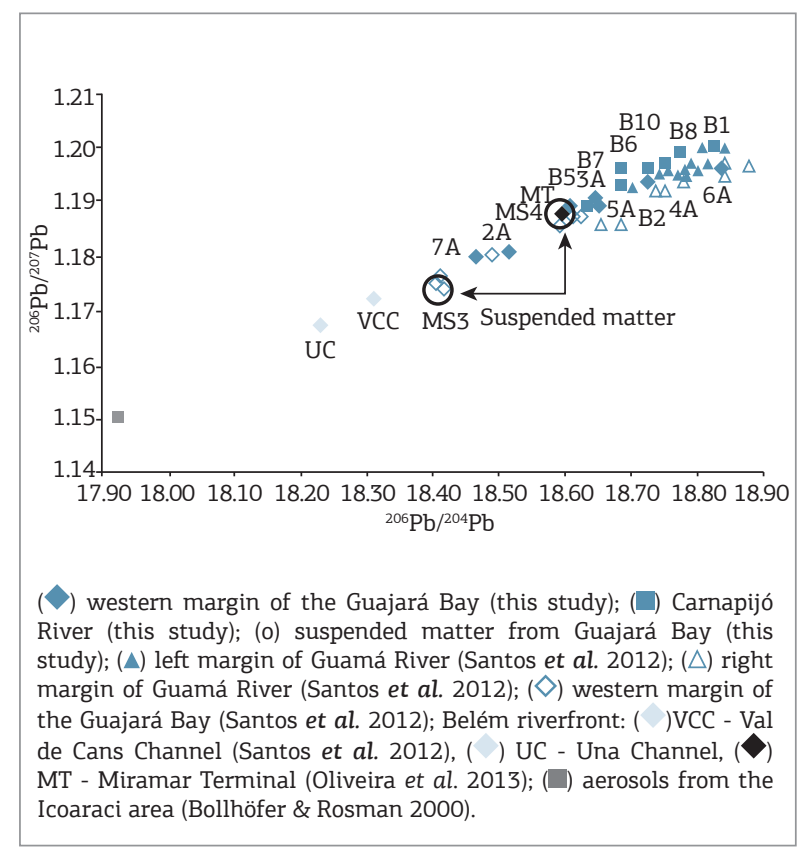

Figure 5. ${ }^{206} \mathrm{~Pb} /{ }^{207} \mathrm{~Pb}$ versus ${ }^{206} \mathrm{~Pb} /{ }^{204} \mathrm{~Pb}$ diagram of bottom sediments, suspended matter, and aerosols. 


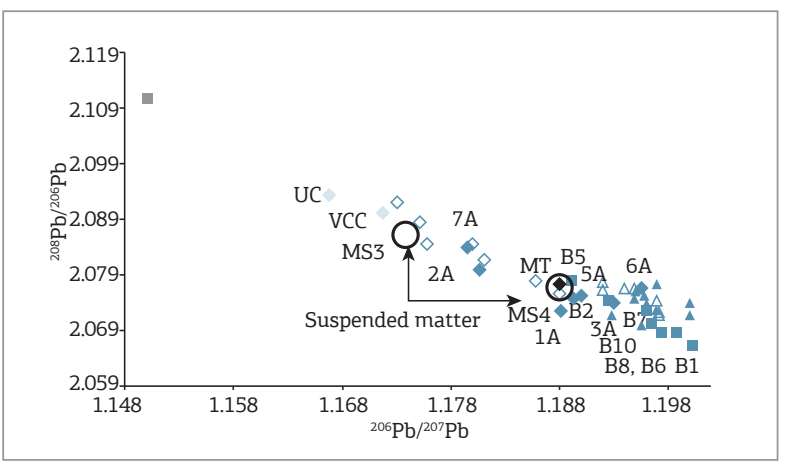

Figure 6. ${ }^{206} \mathrm{~Pb} /{ }^{207} \mathrm{~Pb}$ versus ${ }^{208} \mathrm{~Pb} /{ }^{206} \mathrm{~Pb}$ diagram of bottom sediments, suspended matter, and aerosols (same symbols as those used in Fig. 5). their $\mathrm{Pb}$ isotopic signatures (Lima et al. 2010) also fit the linear trend (not shown in the diagrams).

The isotopic composition of suspended matter is within the range of bottom sediment samples from the Bay and from the mouth of the Una and Val de Cans channels, which is compatible with anthropogenic $\mathrm{Pb}$ dispersal in the hydrographic system mainly by particulates-associated transport. However, the behavior of the isotopic signatures in the ${ }^{206} \mathrm{~Pb} /{ }^{204} \mathrm{~Pb}$ versus ${ }^{206} \mathrm{~Pb} /{ }^{207} \mathrm{~Pb}$ and ${ }^{208} \mathrm{~Pb} /{ }^{206} \mathrm{~Pb}$ versus ${ }^{206} \mathrm{~Pb} /{ }^{207} \mathrm{~Pb}$ diagrams indicates that aerosols cannot be discarded as a possible contributor to the anthropic influence in the bottom sediments of the Guajará bay.

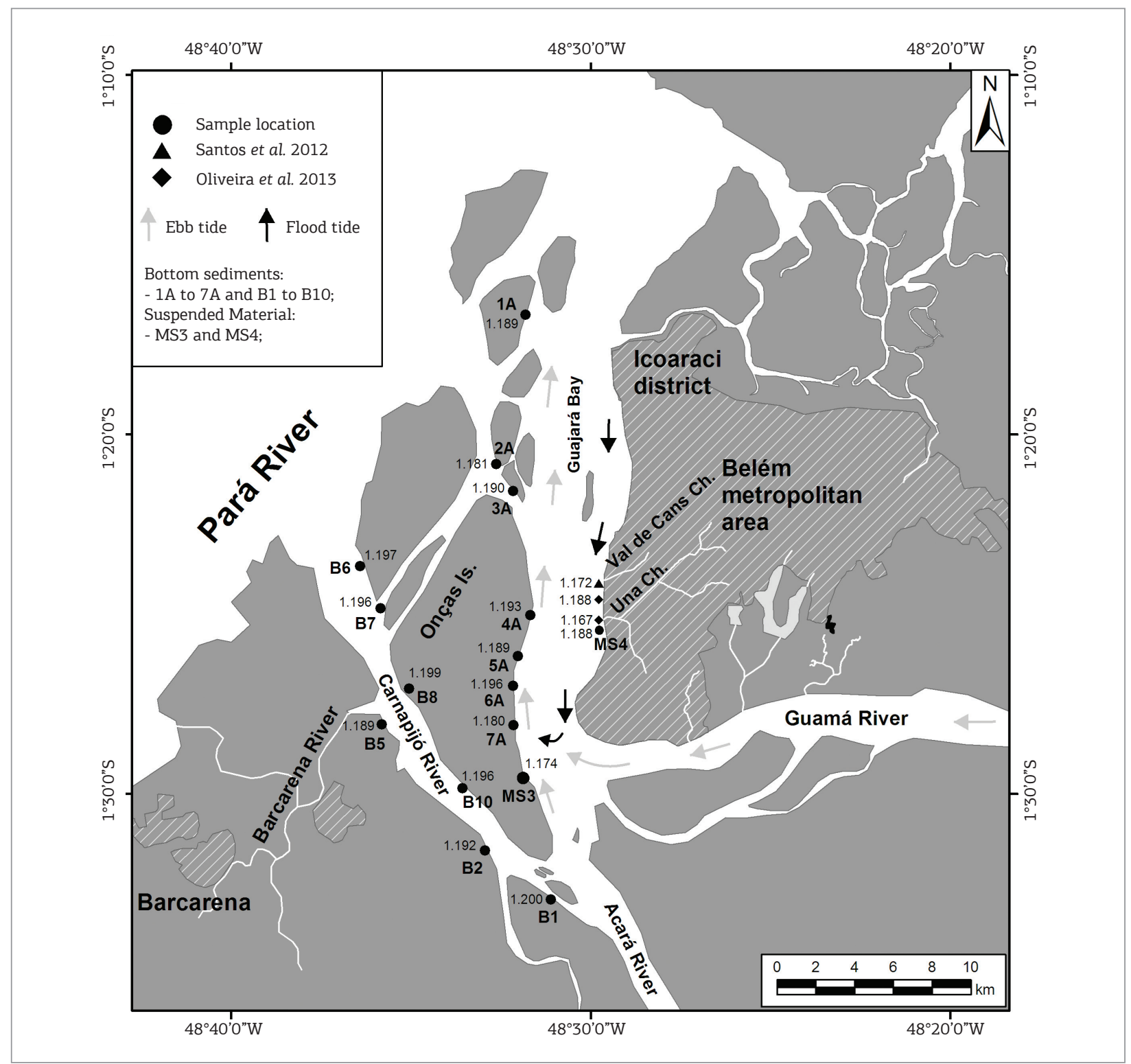

Figure 7. Simplified map of the Belém hydrographic system. ${ }^{206} \mathrm{~Pb} /{ }^{207} \mathrm{~Pb}$ values of the bottom sediments and suspended matter are reported, including those of bottom sediments from the Belém waterfront (Val de Cans Channel - Santos et al. (2012); Miramar terminal and Una Channel - Oliveira et al. (2013)). Tidal and fluvial currents according to Gregório and Mendes (2009) are also displayed. 


\section{CONCLUSIONS}

The isotopic signatures of sediments from the western margin of Guajará Bay confirm an anthropogenic contribution in relation to the presence of $\mathrm{Pb}$, as shown by Santos et al. (2012). However, this contribution is incipient, and as yet no associated environmental damage has occurred.

Throughout the Bay, the accumulation of lead with an anthropogenic origin is related to recent processes that have become more efficient in the last 10 years, as shown by the isotopic signature differences between the Guajará Bay sediments analyzed in this study and those analyzed by Santos et al. (2012). It is considered that such changes may be connected to the rapid population growth within the city of Belém.

In Carnapijó River, isotopic signatures show that this area has not yet been affected by human activity. The mean $\mathrm{Pb}$ concentration $\left(20.5 \pm 4.5 \mathrm{mg} \mathrm{kg}^{-1}\right)$ and isotopic signature $\left({ }^{206} \mathrm{~Pb} /{ }^{207} \mathrm{~Pb}=1.196 \pm 0.004\right)$ confirm the background values previously proposed by Moura et al. (2004) and Santos et al. (2012).

The isotopic signatures of suspended matter from the eastern Belém waterfront $\left({ }^{206} \mathrm{~Pb} /{ }^{207} \mathrm{~Pb}=1.188\right)$ and western margin (the island region: ${ }^{206} \mathrm{~Pb} /{ }^{207} \mathrm{~Pb}=1.174$ ) of Guajará Bay show that domestic sewage from Belém is a major anthropogenic source of $\mathrm{Pb}$ in the Guajará Bay bottom sediments, and that this suspended matter is an efficient transport mechanism of metals to the western margin of the bay. In this respect, there is greater accumulation in the southern part, which is the narrowest section of the Bay, due to the effect of the tides at the confluence with Guamá River. However, the isotopic signatures of $\mathrm{Pb}$ indicate that aerosols cannot be ruled out as possibly contributing to the anthropogenic influence of lead accumulation in Guajará Bay.

Finally, the isotopic results demonstrate the potential of using the isotopic signature of $\mathrm{Pb}$ as a prospective tool for the indication of human activity and the future contamination of bottom sediments, even in a complex hydrodynamic environment within an area that is currently only minimally impacted by human occupation.

\section{ACKNOWLEDGMENTS}

We acknowledge the Conselho Nacional de Desenvolvimento Científico e Tecnológico (CNPq) for the research scholarship granted to ECO, JML and JHC and the CNPq Universal projects (Grant 472146/2008-4 and grant 485539/2012-8) for financial support. In addition, the authors are grateful to the technical staff of the geochronological laboratory of Universidade Federal do Pará (UFPA) for the acquisition of the isotopic data. The authors are thankful to BJG reviewers for their commentaries and constructive suggestions.

\section{REFERENCES}

Acme Analytical Laboratories Ltd. 2009 [Internet]. Available at: http://www.acmelab.com. [cited at Apr. 2009].

Banner J.L. 2004. Radiogenic isotopes: systematics and applications to earth surface processes and chemical stratigraphy. Earth Science Reviews, 65:141-194.

Bird G. 2011. Provenancing anthropogenic Pb within the fluvial environment: Developments and challenges in the use of $\mathrm{Pb}$ isotopes. Environment International, 37:802-819.

Bird G., Brewer P.A., Macklin M.G., Nikolova M., Kotsev T., Mollov M., Swain C. 2010. Quantifying sediment - associated metal dispersal using $\mathrm{Pb}$ isotopes: Application of binary and multivariate mixing models at the catchment - scale. Environmental Pollution, 158:2158-2169.

Bollhöfer A., Rosman K.J.R. 2000. Isotopic source signatures for atmospheric lead: The Southern Hemisphere. Geochimica et Cosmochimica Acta, 64(19):3251-3262.

Bindler R., Renberg I., Anderson N.J., Appleby P.G., Emteryd O., Boyle J. 2001. Pb isotope ratios of lake sediments in West Greenland: inferences on pollution sources. Atmospheric Environment, 35:4675-4685.

Bur T., Probst J.L., N'guessan M., Probst A. 2009. Distribution and origin of lead in stream sediments from small agricultural catchments draining Miocene molassic deposits (SW France). Applied Geochemistry, 24:1324-1338.
Carvalho J.H.S. 2012. Distribuição e registro histórico de metais pesados e assinatura isotópicas de $\mathrm{Pb}$ em testemunhos de sedimentos de fundo da baía do Guajará, Belém-PA. MS Dissertation, Instituto de Geociências, Universidade Federal do Pará, 89p.

Callender, E. 2011. Heavy metals in the environment historical trends In: Holland H.D., Turekian K.K. (eds) Radioactive Geochronometry. New York, Academic Press, Elsevier, 463p.

Dias F.F., Taddei M.H.T., Nascimento S.M., Lafon J.M. 2010. ${ }^{210} \mathrm{~Pb}$ geochronology of sediments from the Guamá River and Guajará Bay in the Amazon region, Belem, Brazil. Atoms for Peace: an International Journal (AFP), 3:26-32.

Dong Z., Bao Z., Wu G. 2010. Lead Concentration Distribution and Source Tracing of Urban/Suburban Aquatic Sediments in Two Typical Famous Tourist Cities: Haikou and Sanya, China. Bull Environment Contamination Toxicological, 85:509-514

Ettler V., Mihaljevic M., Sebek O., Molek M., Grygar T., Zeman J. 2004 Geochemical and $\mathrm{Pb}$ isotopic evidence for sources and dispersal of metal contamination in stream sediments from the mining and smelting district of Príbam, Czech Republic. Environment Pollution, 142:409-417.

Ferrand J.L., Hamelin B., Monaco A. 1999. Isotopic tracing of anthropogenic $\mathrm{Pb}$ inventories and sedimentary fluxes in the Gulf of Lions (NW Mediterranean sea).Continental Shelf Research, 19:23-47. 
Gregório A.M.S., Mendes A.S. 2009. Characterization of sedimentary deposits at the confluence of two tributaries of the Pará River estuary (Guajara Bay, Amazon). Continental Shelf Research, 29:609-618.

Gioia S.M.C.L., Pimentel M.M., Tessler M., Dantas E.L., Campos J.E.G., Guimarães E.M., Maruoka M.T.S., Nascimento E.L.C. 2006. Sources of anthropogenic lead in sediments from an artificial lake in Brasíliacentral Brazil. Science of the Total Environment, 356:125-142.

Helland A., Aberg G., Skei J. 2002. Source dependent behavior of lead and organic matter inthe Glomma estuary, SE Norway: evidence from isotope ratios. Marine Chemistry, 78:149-169.

IDESP. 1990. Um estudo Ambiental do estuário Guajarino. Relatório de Pesquisa, 17, 154p.

Komarék M., Ettler V., Chrastný V., Mihaljevic M. 2008. Lead isotopes in environmental sciences: A review. Environment International, 34:562-577.

Kylander M.E., Klaminder J., Bindler R., Weiss D.J. 2010. Natural lead isotope variations in the atmosphere. Earth and Planetary Science Letters, 1-2:44 -53.

Lafon J.M., Rodrigues E.M.S. Scheller, T. 1993. Geocronologia Pb-Pb em feldspato e rocha total: procedimento experimental e exemplos de aplicação. In: IV Congresso Brasileiro de Geoquímica, Brasília, Boletim resumos expandidos, Brasília/DF, p.242-244.

Lima E.A.R., Siqueira G.W., Lima W.N., Mendes A.S. 2004. Aplicação da técnica de infravermelho na identificação e caracterização da matéria orgânica nos sedimentos de fundo da plataforma continental do Amazonas. Geochimica Brasiliensis, 18(1):46-53.

Lima C.S., Moura C.A.V., Siqueira N.V.M., Galarza M.A. 2010. Determination of the isotope composition of lead and strontium in crude oil and derivatives and prospective environmental applications. In: VII South American Symposium on Isotope Geology, 7, 2010, Brasília, Extended Abstract, CD-ROM.

Loring D.M., Rantala R.T.T. 1992. Manual for the geochemical analyses of marine sediments and suspended particulate matter. Earth Science Review, 32:235-283.

Moraes R.P., Figueiredo B.R., Lafon J.M. 2004. Pb - Isotopic tracing of metal - pollution sources in the Ribeira Valley, Southeastern Brazil. Terrae, 1(1):26-33.

Moura C.A.V., Gaudette H.E., Carvalho M.C., Morales G.P. 2004. The use of lead isotope composition as a tool to investigate the anthropogenic impacts on the environment in the metropolitan region of Belém (PA). Terrae, 1(1):16-25.

Miller J.R., Lechier P.J., Mckin G., Germanoski D., Villarroel L.F. 2007. Evaluation of particle dispersal from milling operations using lead isotopic fingerprinting techniques, Rio Pilcomayo Basin, Bolivia. Science of the Total Environment, 384: 355-373.
Nascimento S.M. 2007. Caracterização da assinatura isotópica de Pb atual e da concentração de metais pesados em sedimentos de fundo da foz do rio Guamá e da baía do Guajará (Belém-Pará). MS Dissertation, Instituto de Geociências, Universidade Federal do Pará, 103p.

Oliveira E.C., Lafon J.M., Corrêa J.A.M., Carvalho J.H.S., Dias F.F., Taddei M.H.T. Avaliação da distribuição dos metais traços em sedimentos de fundo do sistema hidrográfico da região de Belém (margem oeste da baía do Guajará e rio Carnapijó). Geochimica Brasiliensis (in press).

Oliveira S.P., Moura C.A.V., Rosa Filho J.S. 2013. Avaliação de Oligochaeta (Tubificinae) e Polychaeta (Namalycastis abiuma) como bioindicadores da composição isotópica de chumbo: exemplo do estuário guajarino, Belém (PA), Brasil. Pesquisas em Geociências, 40(2): 141-146.

Platzner I., Ehelichs S., Halicz L. 2001. Isotope-ratio measurements of lead in NIST reference materials by multiple-collector inductively coupled plasma mass spectrometry. Journal of Analytical Chemistry, 370: 624-628.

Pejrup, M. 1988. The triangular diagram used for classification of estuarine sediments: a new approach. In: Boer, P.L., Van Gelder, A., Nio, S.D. (eds.). Tide-influenced Sedimentary Environments and Facies. D. Reidel, Dordrecht, p289-300.

Pinheiro, R.V.L. 1987. Estudo hidrodinâmico e sedimentológico do estuário Guajará- Belém (PA). MS Dissertation, Centro de Geociências, Universidade Federal do Pará, 179p.

Roig H.L., Rego A.P.M., Dantas E.L., Meneses P.R., Walde D.H.G., Gioia S.M.L.C. 2005. Assinatura isotópica Sm-Nd de sedimento em suspensão: implicações na caracterização da proveniência dos sedimentos do rio Paraíba do Sul, São Paulo. Revista Brasileira de Geociências, 35(4):503-514.

Rosseti D.F. 2001. Late Cenozoic sedimentary evolution in northeastern Pará, Brazil, within the context of sea level changes. Journal of South American Earth Sciences, 14:77-89.

Santos S.N., Lafon J.M., Corrêa J.A.M., Babinski M., Dias F.F., Taddei M.H.T. 2012. Distribuição e assinatura de $\mathrm{Pb}$ em sedimentos de fundo da foz do rio Guamá e da baía do Guajará (Belém-Pará). Química Nova, 35(2):249-256.

Saraiva A.L.L. 2007. Estudo sedimentológico e geoquímico em sedimentos de fundo da baía do Guajará - Belém (PA).MS Dissertation, Instituto de Geociências, Universidade Federal do Pará, 122p.

Shepard F.P. 1954. Nomenclature based on sand-silt-clay ratios. Journal of Sedimentary Petrology, 24:151-158.

Souza S.R., Oliveira A.O., Hartmann C. 2008. Utilização do testemunhador Russian Pet Borer no Saco do Martins e Arraial, Estuário da Laguna dos Patos: RS, Brasil. Gravel, 6(1):1-13.

Available at www.sbgeo.org.br 